Citation: Soyalın M. \& Battal F., The Relationship Between Perceived Organizational Support And Organizational Commitment In The Context Of Organizational Justice (Example Of Bank Employees), BMIJ, (2020), 8(2): 1721-1752 doi: http://dx.doi.org/10.15295/bmij.v8i2.1461

\title{
THE RELATIONSHIP BETWEEN PERCEIVED ORGANIZATIONAL SUPPORT AND ORGANIZATIONAL COMMITMENT IN THE CONTEXT OF ORGANIZATIONAL JUSTICE (EXAMPLE OF BANK EMPLOYEES)
}

\author{
Mesut SOYALIN 1 \\ Fetullah BATTAL ${ }^{2}$
}

\author{
Received Date (Başvuru Tarihi): \\ Accepted Date (Kabul Tarihi): \\ Published Date (Yayın Tarihi):
}

$30 / 03 / 2020$

$29 / 05 / 2020$

$25 / 06 / 2020$

In the article, the first author is in the role of Corresponding Author.

\begin{abstract}
Keywords:

Organizational Support,

Organizational Commitment,

Organizational Justice
\end{abstract}

JEL Codes:

M10, M 12, M 14

The general aim of this study is to analyze the relationship between organizational support perceived by bank employees, organizational commitment behavior and organizational justice behavior. At the same time, its other purpose is to reveal whether organizational justice plays an intermediary role in the relationship between organizational justice and organizational commitment behavior. In this context, the study was carried out on people working in public and private bank in the province of Bayburt (Turkey). The data in the study were obtained through the survey method. It was then analyzed by structural equation modeling using SPSS and Amos package programs. According to the findings, only the professional experience variable, which constitutes the control variables and demographic information, gave meaningful results with organizational commitment. Secondly, it was observed that the relationship between organizational support, organizational commitment and organizational justice is positive and meaningful in terms of the direction and severity. According to the findings obtained in the last section of the study, it was observed that organizational justice played a partial mediating role in the relationship between organizational support and organizational commitment.

\section{ÖRGÜTSEL ADALET BAĞLAMINDA ALGILANAN ÖRGÜTSEL DESTEK İLE ÖRGÜTSEL BAĞLILIK ARASINDAKİ İLIŞKİ (BANKA ÇALIŞANLARI ÖRNEĞİ)}

$$
\ddot{O Z Z}
$$

Anahtar Kelimeler:

Örgütsel Destek,

Örgütsel Bă̆lılık,

Örgütsel Adalet

JEL Kodlarn:

M 10, M 12, M 14
Bu çalışmanın genel amacı banka çalışanlarının algıladığı örgütsel destek, örgütsel bağhlık davranışı ve örgütsel adalet davranışları arasındaki ilişkiyi ele almaktadır. Aynı zamanda diğer amacı da örgütsel adalet ile örgütsel bă̆lılık davranışı arasındaki ilişkide örgütsel adaletin aracılık rolü oynayıp oynamadığını ortaya koyabilmektir. Bu bağlamda saha araştırması Bayburt ilinde faaliyet gösteren kamu ve özel banka çalışanları üzerinde anket yöntemi ile gerçekleştirilmiştir. Çalışmada veriler anket ile elde edilmiştir. Elde edilen veriler SPSS ve Amos paket programlan kullanılarak yapısal eşitlik modellemesi ile analiz edilmiştir. Ulaşılan genel bulgulara göre ilk önce kontrol değişkenlerini oluşturan, demografik bilgilerden yalnızca mesleki deneyim değişkeni örgütsel bă̆hllı ile anlamlı sonuç vermiştir. İkinci olarak örgütsel destek, örgütsel bağlılık ve örgütsel adalet arasındaki ilişkinin yönüne ve şiddetine bakıldı̆̆ında olumlu ve anlaml yönde olduğu görülmüş̧ür. Çalışmanın son kısmında elde edilen bulgulara göre örgütsel destek ile örgütsel bağhllk arasındaki ilişkide örgütsel adaletin kısmi aracılık rolü üstlendiği görülmüştür.
${ }^{1}$ Dr. Öğr. Üyesi, Siirt Üniversitesi İ.̇̇.B.F, msoyalin@hotmail.com

2 Dr. Öğr. Üyesi, Bayburt Üniversitesi İ.İ.B.F, $\underline{\text { battal@bayburt.edu.tr }}$ https://orcid.org/0000-0003-1475-0905 https://orcid.org/0000-0002-2895-0193 


\section{INTRODUCTION}

Today, organizational commitment has gained importance when qualified personnel management is required. It is the issue of organizational commitment for the skilled workforce to work depending on its organization and to use all its knowledge and skills for the organization. The reason for this situation is the probability that the employees will be successful in the workplace as far as they feel attached to the organization. Otherwise, they will always be looking for opportunities to leave that business and will not be able to provide expected performance. It is not an easy process as it is supposed to bring the individual-organization relationship to a good level. One of the most common problems in practice is the difficulties experienced in establishing individuals' commitment to the organization (Sökmen \& Şİmşek, 2016; Murat \& Sezer, 2017). Especially in the crises experienced in recent years, the idea that the easiest way to reduce the cost is to decrease the number of personnel, and applications such as grade reduction and shrinking of the organization weaken the relations of the employees with their organizations. For this reason, it became an imperative for managers to treat their employees fairly, support them and seek ways to connect their employees to the organization (Hanaysha, 2016; Kim et al., 2016). This study addresses the shaping role of organizational justice in the relationship between the level of organizational support perceived by employees and their commitment to their organizations.

\section{THEORETICAL FRAMEWORK}

\subsection{Perceived Organizational Support}

Perception is a process in which individuals organize and interpret their emotional impressions to make sense of their environment (Robbins, 2003). Perceived organizational support is defined as the employees' perception that their contribution to the organizational system via their activities is acknowledged as a value by the organization they work for and that the organization is concerned with the well-being of them (Hellman et al., 2006). In this context, perceived organizational support is a general perception towards evaluating the overall contributions of the organization's employees and dealing with their well-being (Eisenberger et al.,1986; Wayne et al., 
1997; Kraimer et al., 2001; Yoon and Thye, 2002; Kraimer \& Wayne, 2004; Makanjee et al., 2006; Panaccio \& Vandenberghe, 2009).

\subsection{Organizational Commitment}

Commitment is expressed as the tendency to be within the limits of consistent activity, which is associated with the activities of an individual and is based on awareness of the costs (Allen and Meyer, 1990; Becker, 1960). It is also possible to describe commitment as an emotional loyalty to the organizational goals and values, being biased, the role of the person in relation to the values and goals, and the sacrifice of the person towards the organization (Buchanan, 1974). Some researchers talk about three aspects of this concept. (Maxwell and Steele, 2003; Cohen, 2007; Özdevecioğlu \& Aktaş, 2007; Yozgat \& Şişman, 2007; Uygur, 2009):

1- The acceptance of organizational values and goals, and a strong belief in these goals.

2- Motivation to endeavor towards achieving organizational goals.

3- Having a strong desire to maintain organizational membership.

When employees accept the organization's goals and values, and integrate them into their goals and systems, the commitment is increased (Luthans et al., 1987). According to Meyer and Allen, organizational commitment has two aspects. The first one is that it is related to the nature of loyalty, defined as the relationship between an employee and some other elements, such as an organization, and may differ from person to person. The second one involves the distinguishing effort of an employee between various facts he is committed to. In the classification, these two issues are not opposite (Meyer \& Allen, 1997).

\subsection{Organizational Justice}

The concept of organizational justice emerged after the 1980s under the influence of modern organizational theory and was first named by Greenberg (Greenberg ,1987). In addition, the findings on the literature of administration showed that the concept of "justice" is a subject that philosophers such as Plato, Aristotle, Socrates, Nozick and Rawls has done research about (Colquitt et al., 2001; Greenberg and Bies, 1992). For example; John Rawls expressed justice as the first virtue for social 
institutions (F1rat, 2003). In our daily life, the concept of "justice" means the correctness and suitability of an action or behavior, and expresses the honesty of individuals. In organizational environments, the concept of "organizational justice" describes the justice or fairness of managers in relation to their organizations (Pillai et al., 1999: Colquitt et al., 2001). Organizational justice is the evaluation of managerial decisions for variables such as compliance with the working hours, distribution of duties, empowerment, salary level and reward distribution. When evaluated from this point of view, it can be stated that organizational justice is a concept related to how the management and decisions of the organization management are perceived by the employees (İnce \& Gül, 2005).

\section{HYPOTHESES AND MODEL OF THE RESEARCH}

\subsection{The Relationship between Perceived Organizational Support and Organizational Commitment}

In their study on employees and managers, Eisenberger et al. (1990) showed the existence of a positive and considerable relationship between perceived organizational support and emotional commitment. Shore and Tetrick (1991) found a positive correlation between perceived organizational support and emotional commitment in their work at a US-based multinational company. Similarly, Shore and Wayne (1993) observed a positive and significant relationship between perceived organizational support and emotional commitment. The research was conducted on the employees and the managers of a US-based multinational company. However, they found a negative but not statistically significant relationship between perceived organizational support and continuance commitment.

In their research on food sector workers in Ireland and New Zealand, O'Driscoll and Randall (1999) found a positive relationship between perceived organizational support and emotional commitment, and also a negative relationship between perceived organizational support and continuance commitment. In addition, Bishop et al. (2000) revealed the existence of a positive relationship between perceived organizational support and organizational commitment via their study of automotive industry employees in the United States. Finally, Moideenkutty et al. (2001) analyzed 
the perceived organizational support and emotional commitment of pharmaceutical representatives in India, and the findings revealed a positive relationship between perceived organizational support and emotional commitment.

In order to determine the effects of perceived organizational support on organizational commitment, Özdevecioğlu (2003) conducted a research on staff and workers working at various levels in the furniture sector in Kayseri/ Turkey, and she revealed the following results. First, the relationship between perceived organizational support and normative commitment is positive and considerable, and $18.7 \%$ of normative commitment is explained by organizational support. Second, the relationship between perceived organizational support and emotional commitment is positive and meaningful, and $28 \%$ of emotional commitment is explained by organizational support. Third, the relationship between perceived organizational support and continuance commitment is positive and meaningful, and only $7 \%$ of continuance commitment is explained by organizational support. According to the results, the hypothesis below has been developed:

$\boldsymbol{H}_{1}$ : Perceived organizational support positively and significantly affects the level of organizational commitment.

\subsection{The Relationship between Perceived Organizational Support and}

\section{Organizational Justice}

From the literature review, it is seen that the number of studies examining the direct relationship between perceived organizational support and organizational justice is high. However, studies focusing on the causes and results of the perception of organizational support revealed that perceived organizational support had an intermediate variable effect in the relationship between some independent and dependent variables. For example, Wayne et al. (1997) showed that the perceived organizational support had an intermediate effect on the relationship of human resources activities with emotional commitment, organizational citizenship behavior and tendency to quit. Allen, Shore, and Grifeth (2003) found that the perceived organizational support was an intermediate variable in the relationship between variables such as loyalty and decision-making processes, job security and fair 
distribution of rewards. Rhoades, Eisenberger and Armeli (2001) indicated that the perceived organizational support had an intermediate effect on the relationship of commitment with organizational rewards, procedural fairness and executive support. Within the scope of this information, the hypothesis below has been developed.

$\boldsymbol{H}_{2:}$ The relationship between perceived organizational support and organizational justice is positive and significant.

\subsection{The Relationship Between Organizational Justice and Organizational}

\section{Commitment}

Research results indicate the significant relationship between organizational justice and organizational commitment. For example, Roberts et al. (1999) stated the existence of a positive relationship between organizational justice and organizational commitment. In addition, Folger and Konovsky (1989), McFarlin and Sweeney (1992), Martin and Bennett (1996) determined positive and significant relationships between organizational commitment and organizational justice in their researches.

It has been determined that there is a significant relationship between distributive justice, which is one of the organizational justice dimensions, and organizational commitment (McFarlin and Sweeney, 1992; Randal and Mueller, 1995). Cohen - Charash et al. (2001) determined that distributive justice was related to organizational commitment. In a study conducted by Lowe and Vodanovich (1995) on 138 university management and support staff, it was found that distributive and procedural factors had positive and significant effects on job satisfaction and organizational commitment. According to the findings, the following hypothesis has been created:

$\mathbf{H}_{3}$ : The relationship between organizational justice and organizational commitment is positive and significant.

3.4. The Role of Organizational Justice in the Impact of Perceived Organizational Support on Organizational Commitment

When we look at the researches that examine the relationship between organizational support and organizational commitment, supporting the employees by 
the organization and the fact that the organization takes care of them will keep the employees' mood positive. This positive mood will ensure the commitment of employees to the organization. In studies examining the relationship between perceived organizational support and organizational commitment; although it is concluded that there is a positive relationship between perceived organizational support and emotional and normative commitment, some studies also state the existence of a negative relationship with attendance commitment. Example: (Eisenberger et al., 2002; Bishop et al., 2000; Yoon and Thye, 2002; Moideenkutty et al., 2001; Tumwesigye, 2010; Panaccio et al., 2009). However, a study on the mediating effect of organizational justice has not been reached in the relationship between perceived organizational support and organizational commitment. Therefore, the outcomes to be obtained according to the model of this study are expected to provide a unique contribution to the literature. Based on the outcomes, the following hypothesis has been developed:

$\boldsymbol{H}_{4}$ : Organizational justice has an intermediary effect in the relationship of organizational support with organizational commitment.

The following research model was created according to the empirical research results and explanations stated above.

\section{METHODOLOGY OF THE RESEARCH}

\subsection{Purpose of the Study, Sample and Measurement Tool}

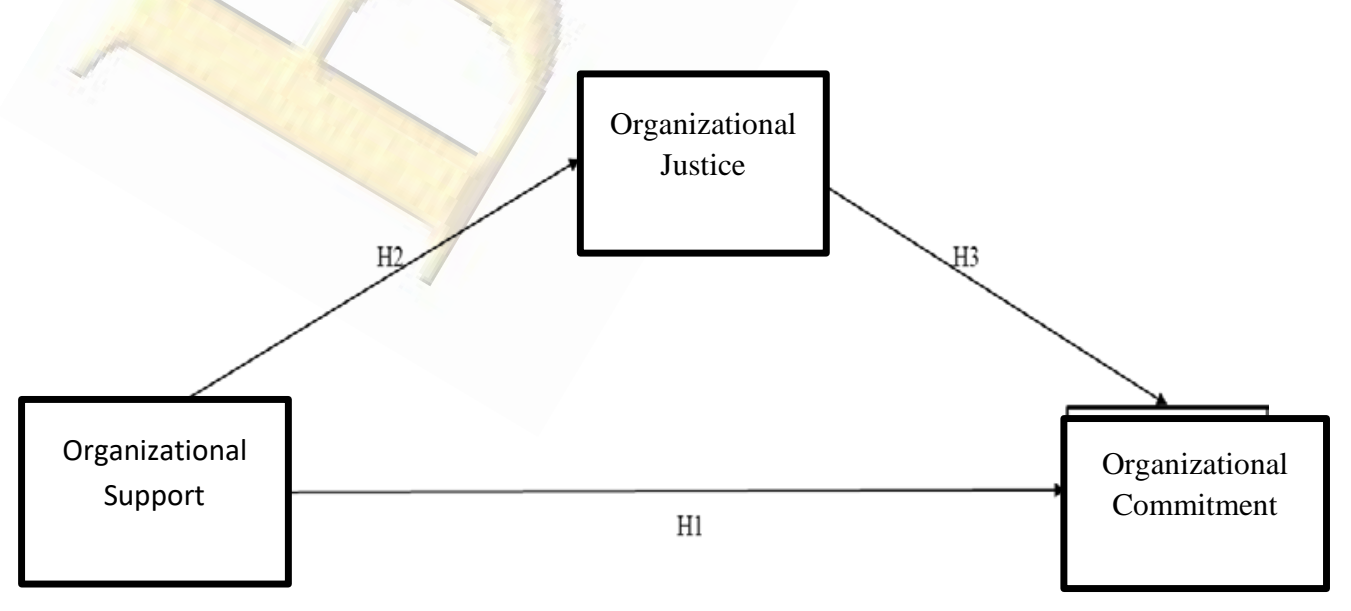

Figure 1. Model of the Research 
This study examines whether the organizational support perceived by employees of some public and private banks in Bayburt province (Turkey) affects their organizational commitment levels and to find out whether organizational justice perceived by employees has a mediating role in this effect. In this context, the promise given to the participants and their managers was kept, and the name of the institution or identity information was not mentioned in any way.

Before initiating the study, it was determined that the main mass to be analysed was 250 people based on the manager permission from the banks decided beforehand and the information obtained from the human resources managers. In the research, the data were obtained via the survey technique. Surveys were collected in December 2019 and ethical committee report is not required. Therefore, 220 questionnaires were distributed to bank employees representing the main body, as a result of this process, 187 surveys were taken into consideration because it was observed that some surveys had some data loss and empty answers. Thus, while $85 \%$ of the distributed questionnaires returned as completed, at least 152 data entry requirements, representing the main mass with $95 \%$ confidence level and $5 \%$ confidence intervals, were achieved. ${ }^{3}$ SPSS and AMOS package programs were used for the analysis of the data.

In order to analyze the perception of organizational support, the short-form organizational support scale used in the study conducted by Eisenberer and Huntington (1986) was applied. Twelve (12) items were used to measure the perceived organizational support in this scale (Eisenberger, et al., 1986).

The second scale used in the research was the organizational justice scale. There were 8 items to measure the perception of organizational justice. In this study, the questionnaire forms made by Greenberg and Baron (2000) were used for the measurement of procedural justice perception, and the questionnaire forms of Karambayya and Brett (1989) were used for the measurement of distributive justice (Karambayya and Brett, 1989). 
The final scale used for the measurement of the employees' organizational commitment was the emotional, normative and continuance commitment scales developed by Meyer and Allen (1991), which also has Turkish forms and commonly used in the literature. This organizational commitment questionnaire developed by Meyer and Allen, in which each commitment dimension includes 8 items, consists of 24 items in total (Meyer \& Allen, 1997). The statements in the scales were asked to be answered according to the 5-point Likert type (1-Strongly Disagree, 5-Strongly Agree). In the questionnaire, gender, age, education status, monthly income, marital status, working position and professional experience factors were considered as the control variables.

\subsection{Findings}

In the study, it was primarily checked whether the data obtained was suitable for normal distribution. For this stage, Kolmogorov-Smirnov and Shapiro-Wilk tests were examined by considering leaf test and histogram tests. Analysis results showed that the data did not show normal distribution. For this reason, non-parametric methods are used.

\subsubsection{Demographic Findings}

Considering the demographic data of the study, it is seen that $68.4 \%$ of bank employees are male and $31.6 \%$ are female. Employees' income status is predominantly (53.4\%) between 3001 and 4500 TL. When the positions of the bank employees are checked, it is seen that mostly $(65.8 \%)$ are composed of bank officers. According to their graduation status, it is seen that undergraduate and graduate education rate is $67,4 \%$, and associate degree and high school education rate is $31,6 \%$. According to the marital status of the participants, the general population $(60.1 \%)$ is married. It is observed that $39.1 \%$ of the bank employees are under the age of 31 and $31 \%$ are between the ages of 31-35. In other words, it can be concluded that the general staff of these banks consists of young and middle-aged people. Considering the professional experience, it is observed that $77.5 \%$ of the employees have 1 to 10 years of professional experience, since the majority of them are young and middle-aged. Finally, those who 
answered yes to the question of whether there is an open-ended management task asked to employees at these or not, are in the minority $(21.9 \%)$.

Table 1. Demographic Information of Bank Employees

\begin{tabular}{|c|c|c|c|c|c|}
\hline Age & $\begin{array}{l}\text { People } \\
\text { N=187 }\end{array}$ & $(\%)$ & Education & $\begin{array}{l}\text { People } \\
\text { N=187 }\end{array}$ & $(\%)$ \\
\hline 25 and below & 34 & 18,2 & Primary Education & 2 & 1 \\
\hline $26-30$ & 40 & 21,4 & High School & 39 & 20,9 \\
\hline $31-35$ & 58 & 31,0 & College / Associate Degree & 20 & 10,7 \\
\hline $36-40$ & 36 & 19,3 & Graduate & 75 & 40,1 \\
\hline 41 and above & 19 & 10,2 & Post Graduate & 51 & 27,3 \\
\hline Position & People & $(\%)$ & Income Level (TL) & People & $\%$ \\
\hline Bank officer & 123 & 65,8 & $3001-4500$ & 100 & 53,4 \\
\hline Assistant Manager & 50 & 26,7 & 4501 and over & 87 & 46,6 \\
\hline Manager & 14 & 7,5 & Marital Satatus & People & $\%$ \\
\hline $\begin{array}{c}\text { Professional } \\
\text { Experience (Year) }\end{array}$ & People & $(\%)$ & Married & 114 & 60,9 \\
\hline $1-5$ & 78 & 41,7 & Single & 73 & 39,1 \\
\hline $6-10$ & 67 & 35,8 & Sex & People & $\%$ \\
\hline $11-15$ & 30 & 16,0 & Female & 59 & 31,6 \\
\hline $16-20$ & 4 & 2,1 & Male & 128 & 68,4 \\
\hline 21 and over & 8 & 4,3 & & & \\
\hline
\end{tabular}

\subsubsection{Factor Analysis Findings Related to Scales}

First, exploratory factor analysis was performed. The reason for this is to reveal the structure of the dimensions of the original scales used according to the data obtained from the study. Then, in the second step, confirmatory factor analysis was made and according to the results obtained, structural equation modeling was made in Amos program.

Exploratory and confirmatory factor analyzes were applied to determine the factor structure of each scale of the study. The explanatory factor analysis was performed on 24 expressions included in the first scale of the study, the organizational commitment scale, and the analysis was repeated after these questions were removed, 
since the factor loads of 4 items were below 0,40 (OC1, OC7, OC13, OC23). Findings of this scale are presented in Table 2. In the table, it is seen that the scale expressions have formed a three-factor structure as in the original scale and all the factors have explained $58.827 \%$ of the total variance. The scale's Cronbach Alpha coefficient of 0,869 shows that the scale is highly reliable (Battal, et al., 2017). In the explanatory factor analysis, the fact that the KMO value was greater than 0,60 revealed that the sample was sufficient, and the rate of sphericity test, which was 000 , showed that significant factors would yield from the expressions (Bland and Altman, 1997). 
Table 2. Explanatory Factor Analysis Results Regarding Organizational Commitment Scale

Factors

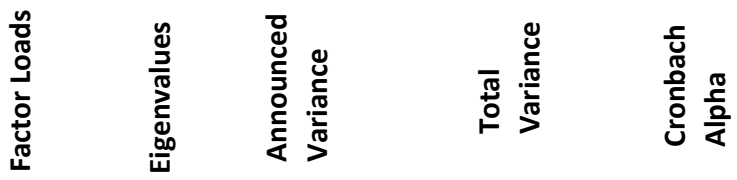

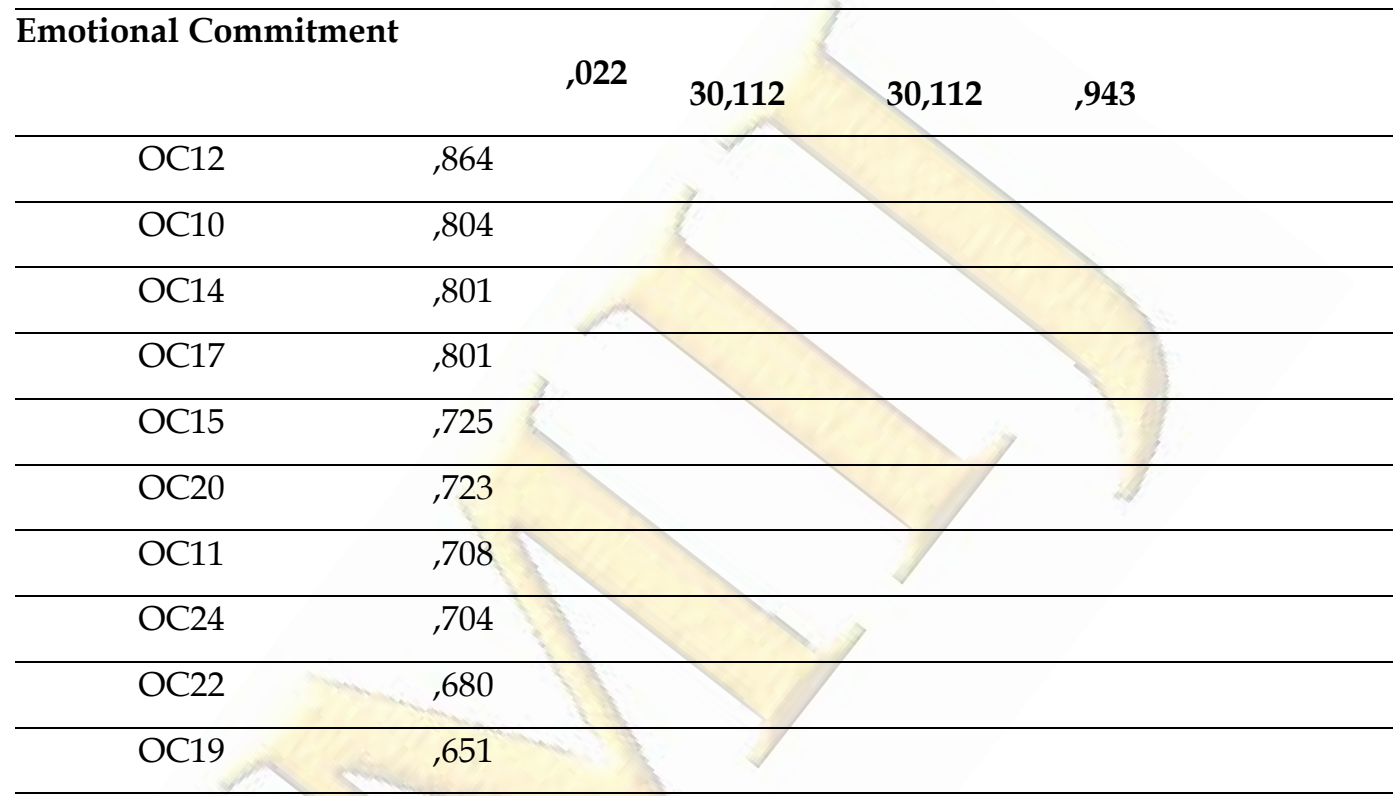

Normative Commitment

$, 976 \quad 19,878 \quad 49,990$

, 870

\begin{tabular}{cc}
\hline OC2 &, 793 \\
\hline OC9 &, 781 \\
\hline OC5 &, 775 \\
\hline OC6 &, 763 \\
\hline OC4 &, 762 \\
\hline OC3 &, 661 \\
\hline OC8 &, 648
\end{tabular}

\begin{tabular}{lllll}
\hline $\begin{array}{l}\text { Continuance } \\
\text { Commitment }\end{array}$ &, 767 & 8,837 & 58,827 &, 773 \\
\hline
\end{tabular}

\begin{tabular}{lll}
\hline OC18 &, 841 & \\
\hline OC21 &, 788 & \\
\hline OC16 &, 458 & \\
\hline KMO $=, 868$ & \multicolumn{1}{l}{ Bartlett Sphericity Test $=190 \quad \mathrm{P}=, 000$} \\
& 1926,202
\end{tabular}


After checking the factor structure of the organizational commitment scale obtained by explanatory factor analysis, this was also tested with confirmatory factor analysis of conformity. It was observed from the findings that the standardized regression coefficient of the expressions was higher than 0.50 , but the expression of 'OC16' below this value was removed. It was also determined that the index values related to the conformity of the scale met the necessary criteria. However, in order to make the necessary improvements in the indices of some items, a modification has been made between OC20 and OC22, OC10 and OC11, and OC19 and OC20. The findings obtained before and after the modification of the scale are given in Table 3.

Table 3. Conformity Index Results Regarding Organizational Commitment Scale

\begin{tabular}{cccc}
\hline Indices & Reference Value & $\begin{array}{c}\text { ValuesBefore } \\
\text { Modification }\end{array}$ & Values After Modification \\
\hline CMIN/DF & $0<\chi^{2} / \mathrm{sd} \leq 5$ & 3,863 & 2,223 \\
\hline SRMR & $<, 05-\leq, 08$ &, 118 &, 080 \\
\hline CFI & $\geq, 90$ &, 826 &, 900 \\
\hline IFI & $\geq, 90$ &, 869 &, 901 \\
\hline TLI & $\geq, 90$ &, 899 &, 069 \\
\hline RMSEA & $<, 05-\leq, 08$ &, 0892 & \\
\hline
\end{tabular}

Figure 2 includes the factor loads of the organizational commitment scale used in the research after modification. 


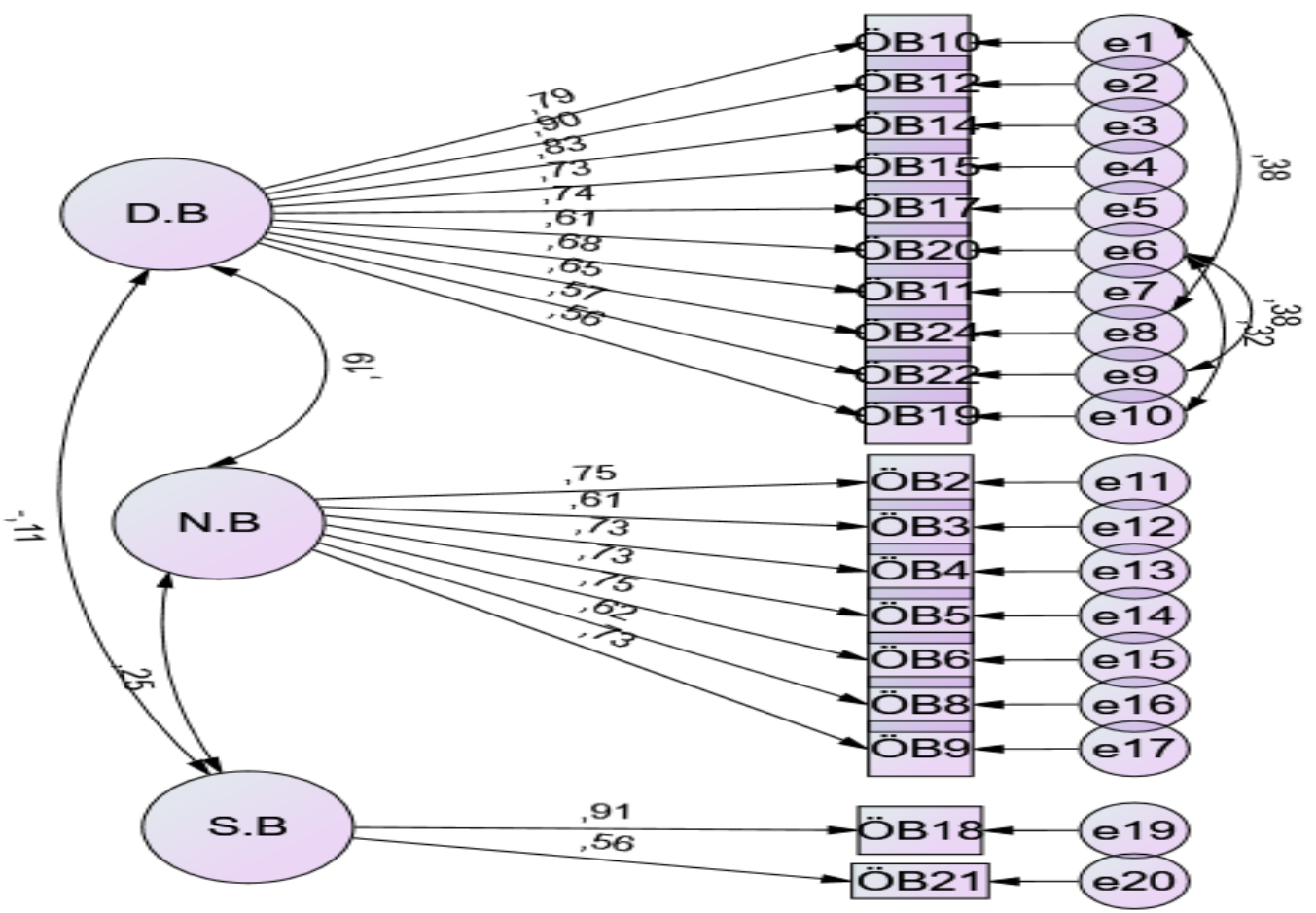

D.A: Distributive Justice N.B: Normative Commitment S.B: Continuance Commitment Ö.B: Organizational Commitment

Figure 2. Conformity Factor Analysis of Organizational Commitment Scale

An explanatory factor analysis was conducted on the organizational justice scale consisting of 8 expressions, which was the second scale used in the research, and it was also paid attention to ensure that the factor load is not below 40. In the analysis made according to these conditions, it was determined that the expressions in the scale displayed a two-factor structure and explained $63.888 \%$ of the total variance. On the other hand, the analysis met the criteria for $\operatorname{KMO}$ value $(, 771)$ and the rate of sphericity test $(, 000)$, and the cronbach alpha coefficient $(, 778)$ indicated that the scale was reliable (Table 4). 
Table 4. Explanatory Factor Analysis Results Regarding Organizational Justice Scale

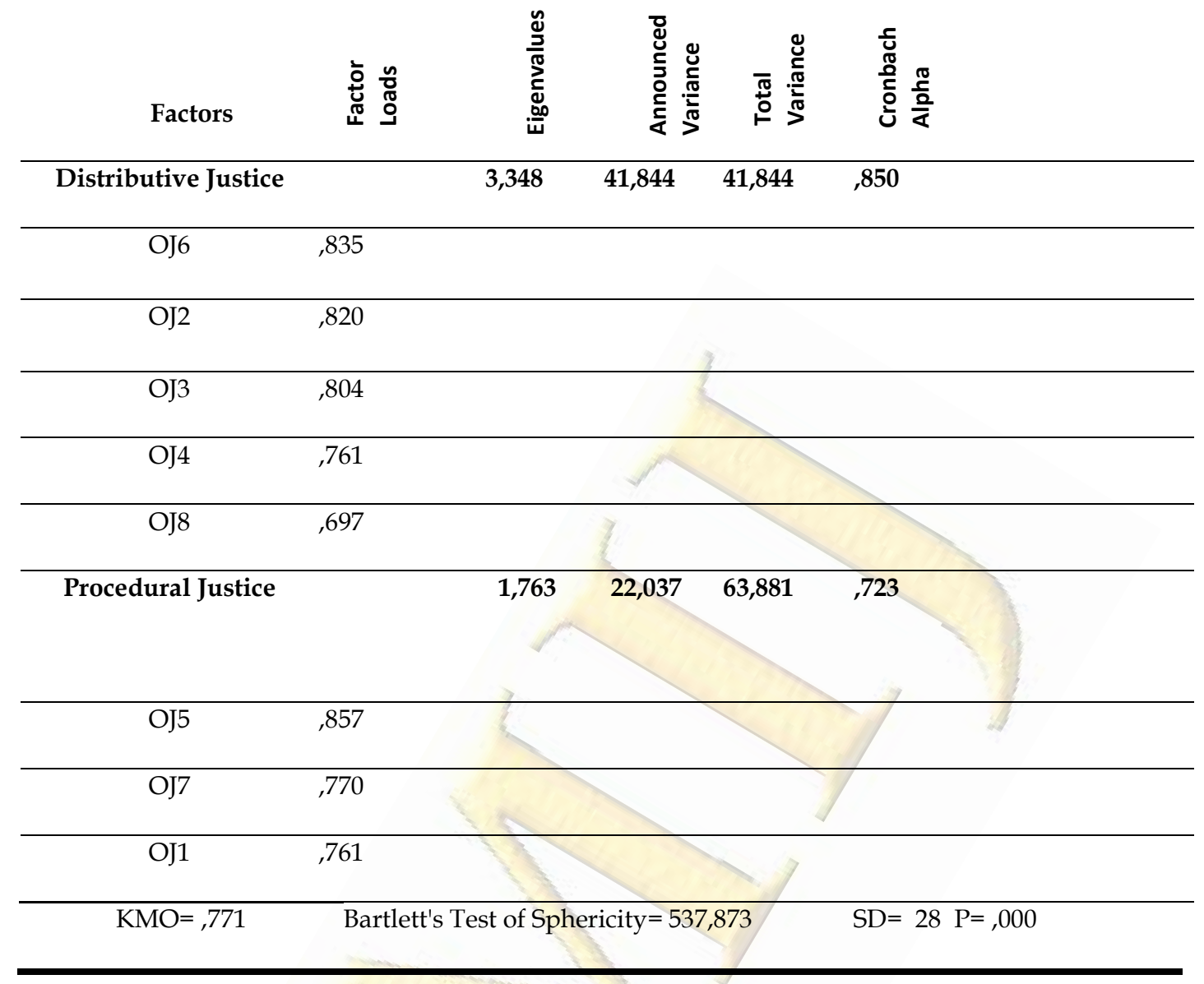

After looking at the factor structure obtained by the explanatory factor analysis of the organizational justice scale, this compatibility was also tested with confirmatory factor analysis. It was observed from the findings that the standardized regression coefficient of the expressions was higher than 0.50 and the index values related to the compatibility of the scale provided the necessary criteria. However, in order to make the necessary improvements in the indices, some items were modified between OJ3 and OJ4, OJ2 and OJ1, and OJ2 and OJ5. The findings obtained before and after the modification of the scale are presented in Table 5. 
Table 5. Compliance Index Results Regarding Organizational Justice Scale

\begin{tabular}{cccc}
\hline Indices & Reference Value & $\begin{array}{c}\text { Values Before } \\
\text { Modification }\end{array}$ & Values After \\
& & Modification \\
\hline CMIN/DF & $0<\chi^{2} / \mathrm{sd} \leq 5$ & 3,745 & 1,974 \\
\hline SRMR & $<, 05-\leq, 08$ &, 083 &, 056 \\
\hline CFI & $\geq, 90$ &, 905 &, 970 \\
\hline IFI & $\geq, 90$ &, 902 &, 971 \\
\hline TLI & $\geq, 90$ &, 899 &, 948 \\
\hline RMSEA & $<, 05-\leq, 08$ &, 864 &, 072 \\
\hline
\end{tabular}

Figure 3 includes the factor loads of the organizational justice scale used in the research after the modification:

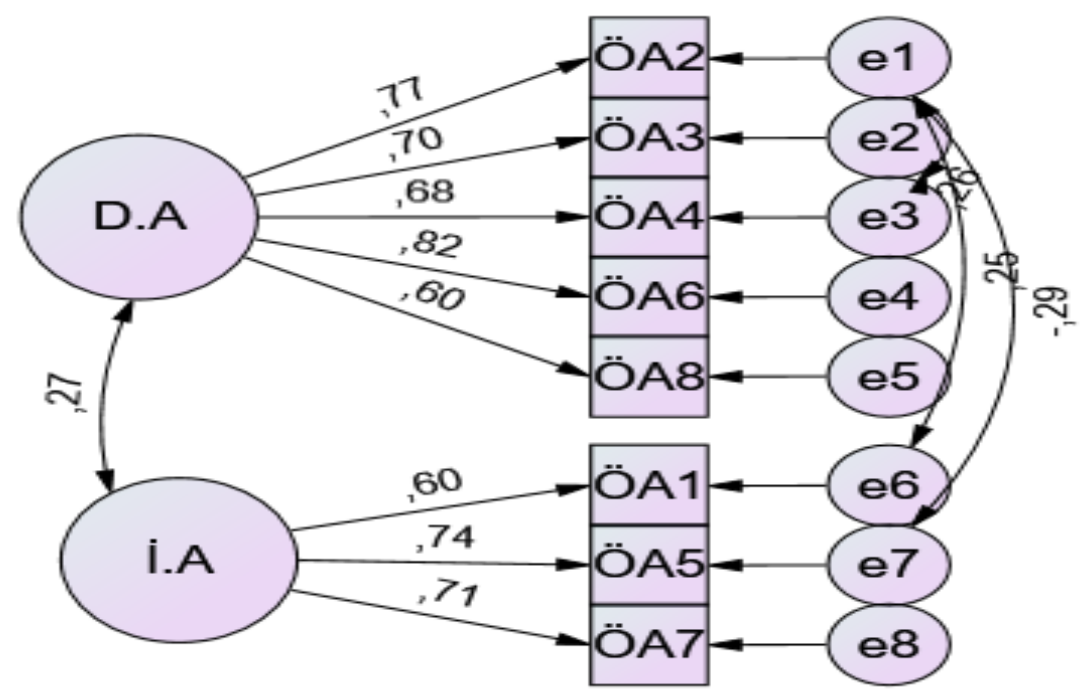

D.A: Distributive Justice İ.A: Procedural Justice Ö.A: Organizational Justice

Figure 3. Conformity Factor Analysis of Organizational Justice

The explanatory factor analysis was applied to the organizational support scale, too, which was the last scale used in the study and consisting of 12 expressions. Since ID12 was the only item which gave a value below 0.40 , it was removed from the scale and the analysis was repeated. In the analysis, it was determined that the expressions in the scale display a single factor structure and explain $61,537 \%$ of the total variance. 
On the other hand, in the analysis, $\mathrm{KMO}$ value $(, 935)$ and sphericity test ratio $(, 000)$ met the necessary criteria and the cronbach alpha coefficient $(, 924)$ showed that the scale was highly reliable (Table 6).

Table 6. Explanatory Factor Analysis Results Regarding Organizational Support Scale

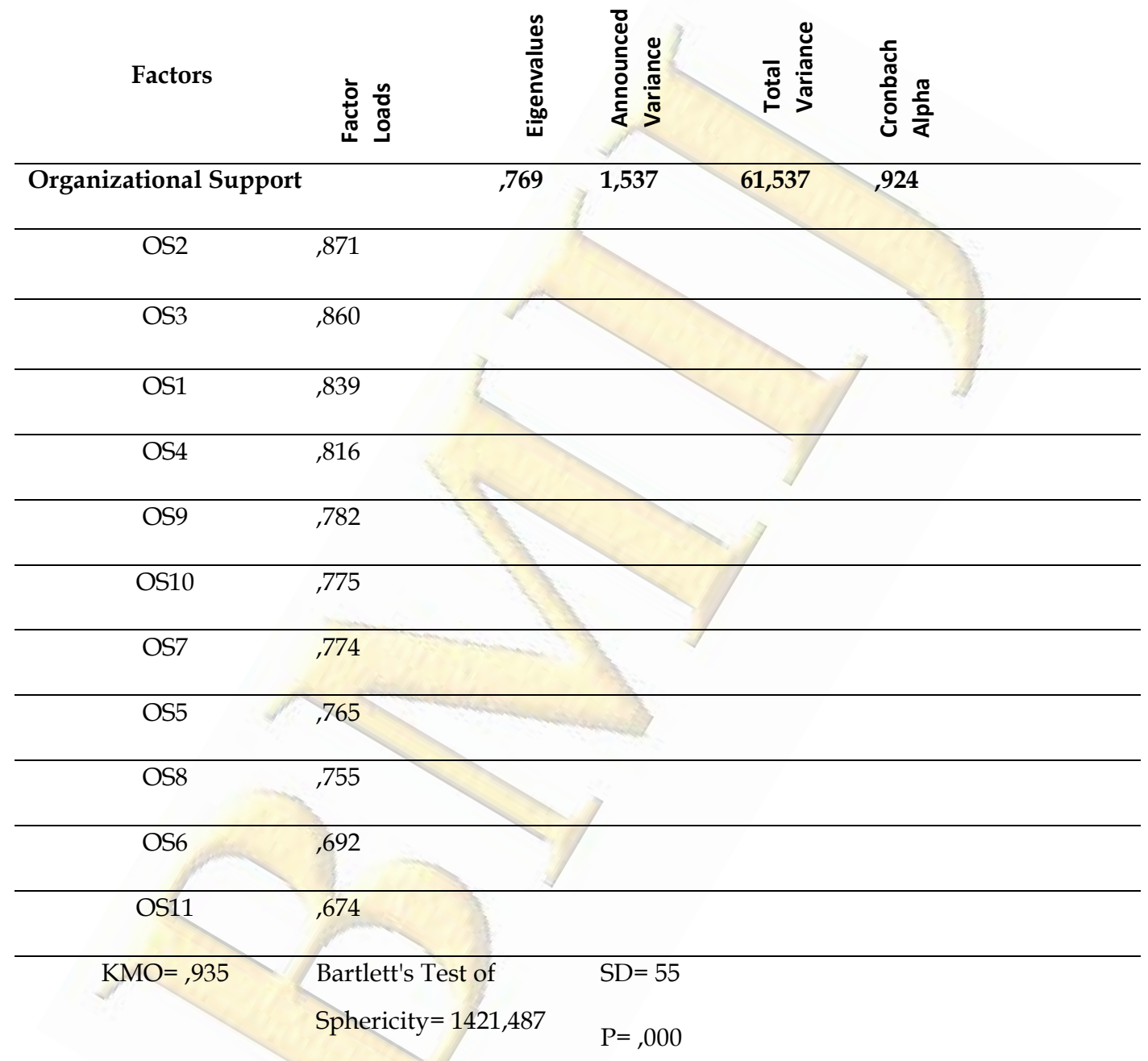

After looking at the factor structure obtained by the explanatory factor analysis regarding the organizational support scale, this was also tested with confirmatory analysis. It was observed that the standardized regression coefficient was higher than 0.50 and index values related to the conformity of the scale met the necessary criteria. However, modifications were conducted between OS4 and OS5, OS3 and OS8, and OS5 and OS11 to provide the necessary improvements for the indices, taking into 
account the Amos program recommendations of some items. The findings obtained before and after the modification of the scale are given in Table 7.

Table 7. Conformity Index Results Regarding Organizational Support Scale

\begin{tabular}{cccc}
\hline Indices & Reference Value & $\begin{array}{c}\text { Values Before } \\
\text { Modification }\end{array}$ & Values After Modification \\
\hline CMIN/DF & $0<\chi^{2} / \mathrm{sd} \leq 5$ & 3,347 & 2,249 \\
\hline SRMR & $<, 05-\leq, 08$ &, 048 &, 039 \\
\hline CFI & $\geq, 90$ &, 926 &, 963 \\
\hline IFI & $\geq, 90$ &, 927 &, 964 \\
\hline TLI & $\geq, 90$ &, 908 &, 951 \\
\hline RMSEA & $<, 05-\leq, 08$ &, 112 &, 076 \\
\hline
\end{tabular}

Factor loads of the organizational support scale after modification are given in Figure 4 below:

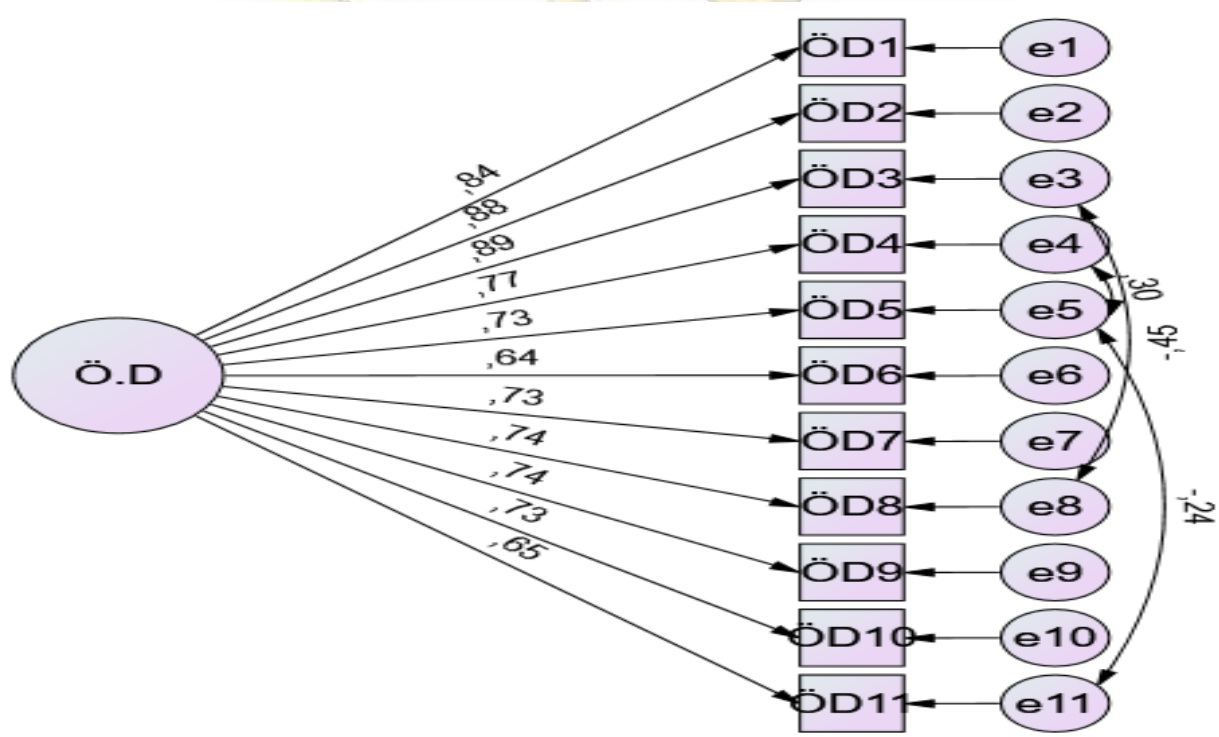

Ö.D:

Organizational Support (O.S)

Figure 4. Conformity Factor Analysis of Organizational Support

\subsubsection{Testing Hypotheses}

In the research, the relationships between bank employees' perceived 
tested by correlation analysis. The Spearman Correlation Analysis was preferred since it was previously determined that the data were not normally distributed in the correlation analysis. Table 8 shows all related findings.

Table 8. Relationship between Variables (Spearman)

\begin{tabular}{|c|c|c|c|c|c|c|c|c|c|c|}
\hline Variables & $\bar{x}$ & SS & 1 & 2 & 3 & 4 & 5 & 6 & 7 & 8 \\
\hline $\begin{array}{l}\text { Organizational } \\
\text { Support }\end{array}$ & 3,793 & ,710 & 1 & & & & & & & \\
\hline $\begin{array}{l}\text { Organizational } \\
\text { Commitment }\end{array}$ & 4,174 & ,567 &, $710^{* *}$ & 1 & & & & & & \\
\hline $\begin{array}{l}\text { Emotional } \\
\text { Commitment }\end{array}$ & 2,685 & ,926 & $193^{* *}$ &, $786^{* *}$ & 1 & & & & & \\
\hline $\begin{array}{l}\text { Normative } \\
\text { Commitment }\end{array}$ & 3,618 & ,759 & $261^{* *}$ & $607^{* *}$ & $148^{* *}$ & 1 & 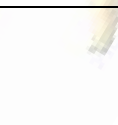 & & & \\
\hline $\begin{array}{l}\text { Continuance } \\
\text { Commitment }\end{array}$ & 3,590 & 825 & $403^{* *}$ & $272^{* *}$ &, $520 * *$ & $265^{* *}$ & 1 & & & \\
\hline $\begin{array}{l}\text { Organizational } \\
\text { Justice }\end{array}$ & 3,190 & ,711 & $428^{* *}$ & $402^{* *}$ & $246^{* *}$ & $254^{* *}$ &, $399^{* *}$ & 1 & & \\
\hline Distributive Justice & 3,503 & 870 & $579^{* *}$ & $171^{* *}$ & $108^{*}$ &, $257^{* *}$ &, $574^{* *}$ & $841^{* *}$ & & \\
\hline Procedural Justice & 2,668 & ,957 & $320^{* *}$ &, $513^{* *}$ & $647^{* *}$ & $131^{* *}$ & $123^{* *}$ &, $565^{* *}$ & $\begin{array}{l}458 \\
* *\end{array}$ & 1 \\
\hline
\end{tabular}

Table 8 shows the averages and standard deviations of variables, and relationships between variables. According to the table, it is observed that bank employees perceive organizational support at medium levels (avg. = 3.793) and organizational commitment behaviors are found to be significantly strong (avg. = 4.174). In addition, the level of organizational justice perceived by the employees (mean $=3.190)$ is observed to be at medium levels. According to Table 9, organizational support perceived by employees and organizational commitment behaviors and perceptions of organizational justice are positively and significantly related at 99\% significance level. In addition, organizational justice perceptions and organizational commitment behaviors of employees are positively and significantly related at $99 \%$ 
significance level. Therefore, as the organizational support perceived by the employees increases, their organizational commitment to the bank will increase positively and significantly with their belief in organizational justice. Additionally, it is seen that the organizational commitment behavior dimensions and organizational justice dimensions of the employees are positively and significantly associated with 99\% significance level. Statistically, it was revealed above that the data were not normally distributed. Based on this, a spearman correlation analysis was performed between the data. Since the correlations between the correlations are high, VIF values were examined at this stage. Therefore, the relationship between variables is shown in Table 9 below.

Table 9. Multiple Linearity Results Between Variables

\begin{tabular}{|c|c|c|}
\hline Variables & Tolerance & VIF \\
\hline Organizational Support &, 547 & 6,258 \\
\hline Organizational Commitment &, 336 & 4,265 \\
\hline Organizational Justice &, 489 & 5,881 \\
\hline
\end{tabular}

After determining the severity and direction of the relationship between variables, hypotheses were tested. Hierarchical regression analysis method was preferred for the hypothesis testing and research model. Before conducting hierarchical regression analysis, it was determined by examining the variance magnification diameter (Variance Infilation Factor-VIF) and tolerance indices of the variables (variance rate that could not be explained by the variables) whether there was a multiple linearity problem among the variables. Since the VIF value of the variables was not above 10 and the tolerance value not below 0.10 , there was no multiple linear connection problem. Therefore, it was concluded that a hierarchical regression analysis could be performed (O'brien, 2007).

The effect caused by control variables such as gender, age and educational status on the organizational commitment variable was defined in the first step of the regression analysis. In the second step, the organizational support, which is an 
independent variable, was included in the regression equation. Then the direct effect of perceived organizational support on organizational commitment was evaluated. As the last step, the variable of the interaction between organizational support and organizational justice perception was included in the equation. Obtained outcomes are presented in Table 10 below.

Table 10. Hierarchical Regression Findings

\begin{tabular}{|c|c|c|c|c|c|c|c|c|c|}
\hline Variables & & t Step ( & del-1) & 2nd $S$ & ep (Mo & 1-2) & & (Mode) & \\
\hline & $\beta$ & $\mathrm{T}$ & p & & $\mathrm{t}$ & $\mathrm{P}$ & $\beta$ & $\mathrm{t}$ & $\mathrm{p}$ \\
\hline Sex &,- 114 & $-1,518$ & 131 &,- 118 & $-1,584$ & ,115 &,- 080 & $-1,152$ & 251 \\
\hline Age &,- 117 & $-1,047$ & ,296 &,- 103 &,- 932 & 353 &,- 080 &,- 775 & 439 \\
\hline Education & 178 & 1,509 & 133 & 184 & 1,572 & ,118 & 193 & 1,781 & ,077 \\
\hline $\begin{array}{l}\text { Administrative } \\
\text { Task }\end{array}$ &,- 109 & $-1,513$ & 132 &,- 116 & $-1,616$ & 108 & -089 & $-1,334$ & 184 \\
\hline Income & 083 & 650 & ,516 & , 097 & 759 & ,449 & , 065 & ,549 & ,583 \\
\hline $\begin{array}{l}\text { Professional } \\
\text { experience }\end{array}$ & ,236 & 2,297 & ,023 &, 223 & 2,181 & 030 & 165, & 1,736 & , 084 \\
\hline $\begin{array}{l}\text { Organizational } \\
\text { Support }\end{array}$ & - & & & ,147 & 2,084 & ,039 &,- 063 &,- 838 & 403 \\
\hline $\begin{array}{l}\text { Organizational } \\
\text { Support } \\
\text { Organizational } \\
\text { Justice }\end{array}$ & & & & - & - & - & ,418 & 5,541 & , 000 \\
\hline $\mathbf{R}^{2}$ & 112 & & & 133 & & & ,260 & & \\
\hline Corrected $\mathrm{R}^{2}$ & 082, & & & 099, & & & ,227 & & \\
\hline $\mathbf{F}$ & $3,773^{* *}$ & & & $3,914^{* *}$ & & & $7,830^{* *}$ & & \\
\hline$\Delta \mathbf{R}^{2}$ & - & & & , 021 & & & 127 & & \\
\hline
\end{tabular}

The regression analysis results given in Table 10 (Step 1) are examined and it is observed that control variables are not capable to affect organizational commitment as 
a whole, since they don't have enough power, and only professional experience differs significantly $(\mathrm{F}=3,773$ and $\mathrm{p}=, 023)$.

In the second step of the regression analysis, the perceived organizational support was included in the analysis and significant results were obtained $(F=3.914$ and $\mathrm{p}=$, 039). Therefore, organizational support positively and significantly affected organizational commitment behavior $(\beta=, 147$ and $\mathrm{p}=, 039)$. At this stage of the analysis, organizational support explained the organizational commitment behavior together with the control variables by $13 \%$. Moreover, the explanatory power of the second step was found to be higher and more significant than the previous step $(\Delta R 2$ $=, 021$ and $\mathrm{p}<, 001)$, so it was determined that the second model could better explain the organizational commitment behavior.

In the third step, in which the interaction between organizational support and organizational justice was included in the analysis, the model presented significant results $(F=7.830$ and $p=000)$. At this stage, in which there were direct and indirect effects, $26 \%$ of organizational commitment behavior was explained. The power of relative explanation was higher compared to the second one and statistically more important $(\triangle \mathrm{R} 2=, 127$ and $\mathrm{p}<, 000)$. After direct relationships are revealed, hierarchical regression analysis, which is free from the control variables and given in Table 11, was conducted again in order to clearly demonstrate the mediation effect. 
Table 11. Regression Analysis of the Mediating Role of Organizational Justice in the Relationship between Organizational Support and Organizational Commitment

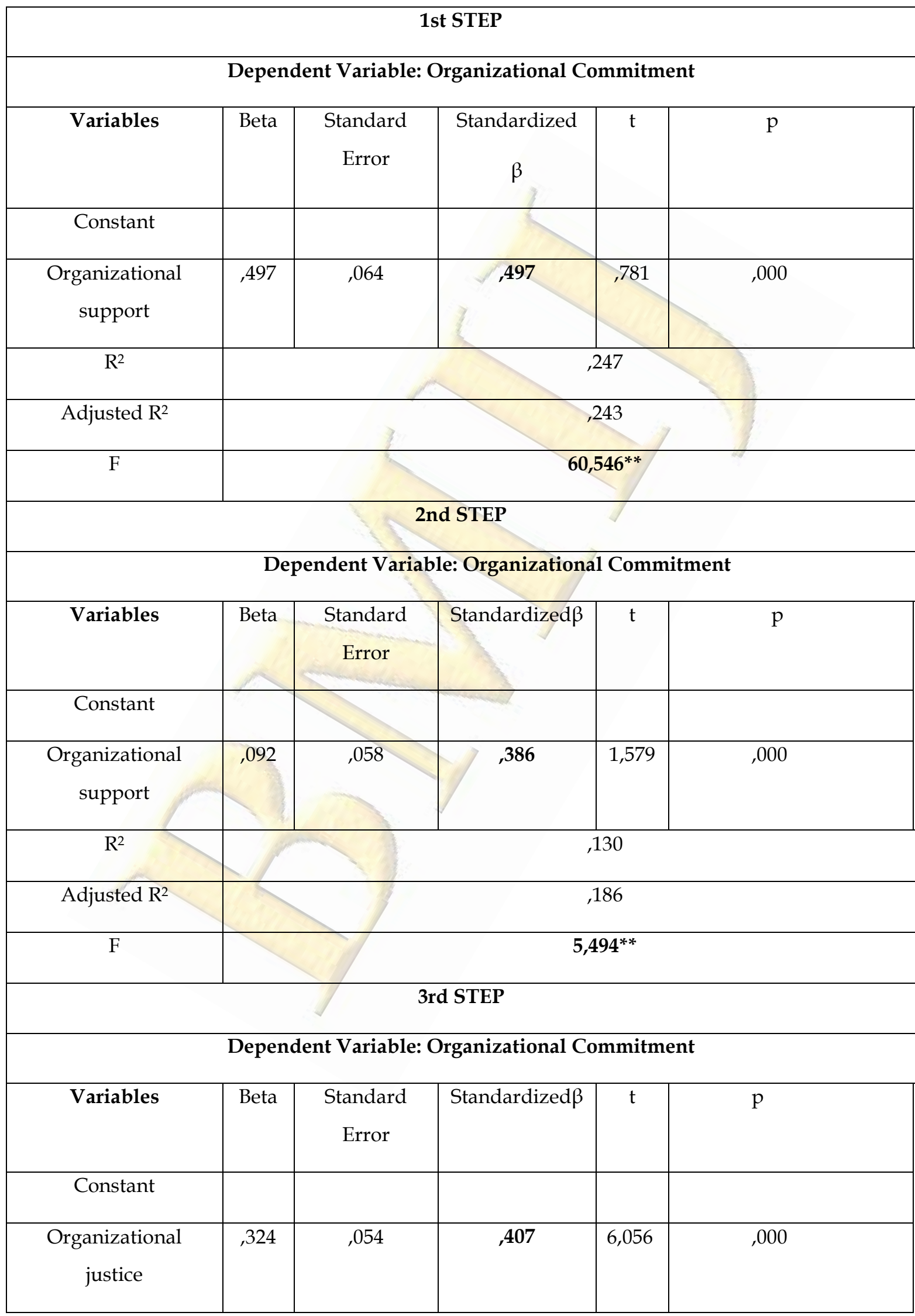




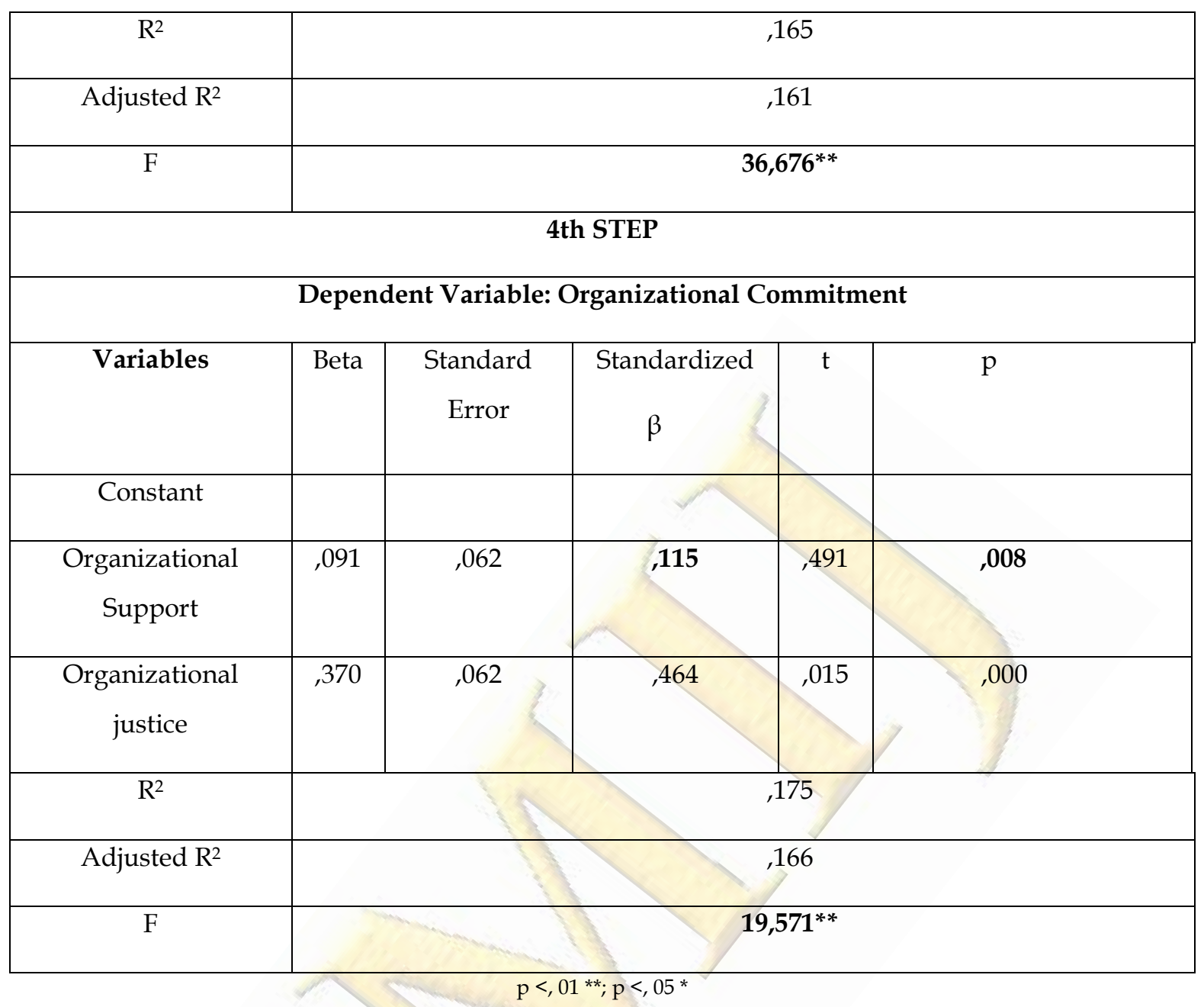

Mediation criteria of Baron and Kenny (1986) were taken into consideration while conducting the mediation test (Baron \& Kenny, 1986).

If the effect of the independent variable on the dependent variable decreases significantly with the addition of the intermediary variable to the model, there is partial mediation; If the effect of the independent variable on the dependent variable disappears completely and becomes meaningless, full mediation is available.

Based on this information, in order to reveal whether organizational justice plays a mediating role in the effect of the perception of organizational support on organizational commitment behavior, the direct effect of organizational support on the organizational justice variable was analyzed. The F test of the analysis performed in this step gave significant results $(F=60,546 \mathrm{p}<0,01)$ and it was found that organizational support explained approximately $24 \%$ of the total variance of the organizational justice variable $\left(\mathrm{R}^{2}=0.247\right)$. Additionally, as shown in Table 10 , the 
perception of organizational support affected the organizational justice variable at $99 \%$ significance level $(\beta=0.497$ and $\mathrm{p}=0.000)$. $\mathrm{H}_{2}$ was accepted.

In the second step of the analysis, the direct effect of organizational support was investigated in order to determine its effect on organizational commitment behavior. The $F$ test of the model in this step gave a significant result $(F=5,494 p<0,01)$. The perception of organizational support explained about $13 \%$ of the total variance of organizational commitment behavior $\left(R^{2}=0.130\right)$. The findings revealed that the perception of organizational support affected organizational commitment behavior at $99 \%$ significance level $(\beta=0.386$ and $p=0.000)$. As a result of all analysis, $\mathrm{H}_{1}$ was accepted.

In the third step of the analysis, the direct impact of the perception of organizational justice on organizational commitment was examined. In this step, F test gave a meaningful result $(\mathrm{F}=36,676 \mathrm{p}<0,01)$. The perception of organizational justice explained about $16 \%$ of the total variance of organizational commitment behavior $\left(\mathrm{R}^{2}\right.$ $=0,165)$. The findings showed that the perception of organizational justice affected the organizational commitment behavior at $99 \%$ significance level $(\beta=0.407$ and $p=$ 0.000). Based on all the results, $\mathrm{H}_{3}$ was accepted.

Finally, as a mediator variable, the organizational justice was included in the model and the analysis was repeated. The results showed that the effect of organizational support perception on organizational commitment behavior decreased, with the inclusion of this variable in the model, compared to the direct effect $(\beta=0.115$ and $p=0.008)$. In the final situation, the partial role of organizational justice variable in the relationship between the perception of organizational support and organizational commitment behavior was determined. Based on all the findings obtained, H4 was accepted.

\section{DISCUSSION AND CONCLUSION}

This study was carried out in order to find out whether organizational justice perception has a mediating role in the relationship between perceived organizational support and organizational commitment behavior. For this purpose, firstly, the 
concepts of organizational support, organizational commitment and organizational justice were discussed in detail and thus a theoretical framework was created.

After the theoretical framework was created, various studies that deal with these concepts together in order to reveal the interaction between organizational support, organizational commitment and organizational justice were examined through the literature review. In these studies, it was seen that organizational support affected organizational commitment positively and significantly (Özdevecioğlu, 2013; Aube, Rousseau \& Morin, 2007), and organizational support was found to have a significant and positive relationship with organizational justice (De Coninck, 2010; Tokgöz, 2011).

Furthermore, organizational justice and organizational commitment behavior studies were also considered and it was observed that there were significant and positive relations between these concepts (Yazıcığlu \& Topaloğlu, 2009; Crow, Lee \& Joo, 2012). Based on those mentioned studies, a research model was designed and hypotheses were formed in line with this model.

Employees from banking sector were selected as samples in order to examine the research hypotheses. The reasons such as the fact that the banking sector is one of the rapidly developing and transforming sectors, the number of employment it provides is constantly increasing, and the research variables are suitable for evaluating the perceptions and behaviors of the employees in this sector have made it appropriate to select the sample of the research from this field. On the other hand, due to constraints such as time, cost and accessibility, only public and private bank employees working in Bayburt (Turkey) were selected as the main body. The questionnaire method was used in the research. The results obtained from the survey of 187 bank employees are summarized below:

Firstly, the reliability level of each scale used related to the variables was examined. Cronbach alpha coefficient was used as a criterion in determining the reliability of the scales. In performed analysis, it was seen that the reliability levels of each scale for the variables were within the acceptable limits. Then, explanatory factor analyzes were applied to each scale, respectively, and thus factor structures were 
determined. As a result of conducted analysis, the organizational commitment scale showed that it had a three-factor structure, organizational justice had a two-factor, and the organizational support scale had a single-factor structure. While the dimensions of organizational commitment behavior were "emotional commitment", "normative commitment", "continuance commitment", the dimensions of organizational justice were "distributive Justice" and "procedural Justice".

Correlation and regression analyze were applied in order to test the hypotheses showing the predicted relationships between the variables in the research model. Conducted analysis revealed that there were relationships at a level of 99\% significance between the perceived organizational support, organizational commitment and organizational justice. The direction, severity and dimensions of the relationship between the variables were revealed by correlation analysis. Therefore, only the relationships between the general states of the scales were discussed in the hierarchical regression section.

It has been determined that there is a direct and moderate relationship between organizational support and organizational commitment behavior. Based on this result, it is suggested that the organizations' feeling of the support they provide to their employees (perception of support) will increase the loyalty of the employees to the organization and thus the number of people who think of leaving the organization will decrease.

Finally, when the role of organizational justice is examined in the relationship between organizational support and organizational commitment in the hierarchical regression analysis, the regression coefficient decreases with the inclusion of organizational justice in the model compared to the direct relationship between organizational support and organizational commitment, but a significant result emerges. Therefore, a partial mediating role of justice was observed in the relationship between perceived organizational support and commitment. This result may show that when the level of support perceived by the employees increases, their belief in justice may increase with their commitment to organization. It is expected that this 
study will be a guide and provide a different idea for managers and researchers in the bank sector.

This study also has some limitations. For example, the use of cross-sectional data that measures the instantaneous perception status, as well as the study is carried out only in one province and on pre-determined banks, is the main restriction of the study. In future studies on this subject, it is thought that the study can produce more profound results by adding longitudinal data, namely test repetition methods and cultural variables. 


\section{REFERENCES}

Allen, D., Shore, L.M., \& Griffeth, R.W. (2003). The Role of Perceived Organizational Support and Supportive Human Resource Practices in the Turnover Process, Journal of Management, 29, 99118.

Allen, N. J., \& Meyer, J. P. (1990). The Measurement and Antecedents of Affective, Continuance and Normative

Aube, C., Rousseau, V., \& Morin, E. M. (2007). Perceived Organizational Support and Organizational Commitment: The Moderating Effect of Locus of Control and Work Autonomy, Journal of Managerial Psychology, 22(5), 479-495.

Baron, R.M. and Kenny, D.A. (1986). The Moderator-Mediator Variable Distinction in Social Psychological Research Conceptual, Strategic and Statistical Considerations, Journal of Personality and Social Psychology, 51(6), 1173-1182.

Battal, F., Durmuş, İ., \& Çınar, E. (2017). The Effects of Organizational Citizenship Behaviors and Decision-Making Styles on Transformational Leadership Behavior, Electronic Turkish Studies, 12(31).1-28.

Becker, H. S. (1960). Notes on The Concept of Commitment, American Journal of Sociology, 66(1), 3240.

Bishop, J. W., Scott, K. D., \& Burroughs, S. M. (2000). Support, Commitment and Employee Outcomes in A Team Environment, Journal of Management, 26(6), 1113-1132.

Bland, J. M., \& Altman, D. G. (1997). Statistics Notes: Cronbach's Alpha, Bmj, 314(7080), 572.

Bruce, Buchanan, I. I. (1974). Building Organizational Commitment: The Socialization of Managers in Work Organizations, Administrative Science Quarterly, 19(4), 533-546.

Buchanan, B. (1974). Government managers, business executives, and organizational commitment. Public Administration Review, 339-347.

Cohen, A. (2007). Commitment Before and After: An Evaluation and Reconceptualization of Organizational Commitment, Human Resource Management Review, 17(3), 336-354.

Cohen-Charash-Charash, Y. and P. E. Spector (2001), The Role of Justice in Organizations: A MetaAnalysis, Organizational Behavior and Human Decision Processes, 86, 278-321.

Colquitt, J. A., Conlon, D. E., Wesson, M. J., Porter, C. O., \& Ng, K. Y. (2001). Justice at The Millennium: A Meta-Analytic Review of 25 Years of Organizatioanl Justice Research. Journal of Applied Psychology, 86(3), 425-445.

Commitment to The Organization, Journal of Occupational Psychology, 63(1), 1-18.

Crow, M. S., Lee, C. B., \& Joo, J. J. (2012). Organizational Justice and Organizational Commitment Among South Korean Police Officers: An Investigation of Job Satisfaction As A Mediator. Policing: An International Journal of Police Strategies \& Management, 35(2), 402-423.

De Coninck, J. B. (2010). The Effect of Organizational Justice, Perceived Organizational Support, And Perceived Supervisor Support on Marketing Employees' Level of Trust, Journal of Business Research, 63(12), 1349-1355.

Eisenberger, R., Fasolo, P., \& Davis-LaMastro, V. (1990). Perceived Organizational Support and Employee Diligence, Commitment, and Innovation, Journal of Applied Psychology, 75(1), 51.

Eisenberger, R., Huntington, R., Hutchison, S., \& Sowa, D. (1986). Perceived Organizational Support, Journal of Applied Psychology, 71(3), 500-507.

Eisenberger, R., Huntington, R., Hutchison, S., \& Sowa, D. (1986). Perceived organizational support. Journal of Applied psychology, 71(3), 500. 
Eisenberger, R., Stinglhamber, F., Vandenberghe, C., Sucharski, I. L., \& Rhoades, L. (2002). Perceived Supervisor Support: Contributions to Perceived Organizational Support and Employee Retention, Journal of Applied Psychology, 87(3), 565-573.

Fırat, A. S. (2003). Çevre Etiği Kavramı Üzerine Yeniden Düşünmek, Ankara Üniversitesi Siyasal Bilgiler Fakültesi Dergisi, 58(3), 105-144.

Folger, R., \& Konovsky, M. A. (1989). Effects of Procedural and Distributive Justice on Reactions to Pay Raise Decisions, Academy of Management Journal, 32(1), 115-130.

Greenberg, J. (1987). A taxonomy of organizational justice theories. Academy of Management review, 12(1), 9-22.

Greenberg, J. and Baron, R. A. (2000), Behavior in Organizations (New Jersey: Prentice Hall, Seventh Edition).

Greenberg, J., \& Bies, R. J. (1992). Establishing The Role of Empirical Studies of Organizational Justice in Philosophical Inquiries İnto Business Ethics, Journal of Business Ethics, 11(5-6), 433-444.

Hanaysha, J. (2016). Examining the effects of employee empowerment, teamwork, and employee training on organizational commitment. Procedia-Social and Behavioral Sciences, 229(298-306), 298306.

Hellman, C. M., Fuqua, D. R., \& Worley, J. (2006). A Reliability Generalization Study on The Survey of Perceived Organizational Support: The Effects of Mean Age and Number of Items on Score Reliability, Educational and Psychological Measurement, 66(4), 631-642.

https://www.surveysystem.com/sscalc.htm 06.12.2019

İnce, M., \& Gül, H. (2005). Yönetimde Yeni Bir Paradigma: Örgütsel Bağlılık. Konya: Çizgi Kitabevi.

Karambayya, R., \& Brett, J. M. (1989). Managers Handling Disputes: Third-Party Roles and Perceptions of Fairness, Academy of Management Journal, 32(4), 687-704.

Kim, K. Y., Eisenberger, R., \& Baik, K. (2016). Perceived organizational support and affective organizational commitment: Moderating influence of perceived organizational competence. Journal of Organizational Behavior, 37(4), 558-583.

Kraimer, M. L., \& Wayne, S. J. (2004). An Examination of Perceived Organizational Support As A Multidimensional Construct in The Context of An Expatriate Assignment, Journal of Management, 30(2), 209-237.

Kraimer, M. L., Wayne, S. J., \& Jaworski, R. A. A. (2001). Sources of Support and Expatriate Performance: The Mediating Role of Expatriate Adjustment, Personnel Psychology, 54(1), 71-99.

Lowe, R. H., \& Vodanovich, S. J. (1995). A Field Study of Distributive and Procedural Justice as Predictors of Satisfaction and Organizational Commitment, Journal of Business and Psychology, 10(1), 99-114.

Luthans, F., Baack, D., \& Taylor, L. (1987). Organizational Commitment: Analysis of Antecedents, Human Relations, 40(4), 219-235.

Makanjee, C. R., Hartzer, Y. F., \& Uys, I. L. (2006). The Effect of Perceived Organizational Support on Organizational Commitment of Diagnostic Imaging Radiographers, Radiography, 12(2), 118-126.

Martin, C. L. and N. Bennett (1996), The Role of Justice Judgments in Explaining the Relationship Between Job Satisfaction and Organization Commitment, Group and Organization Management, 21(1), 84-104.

Maxwell, G., \& Steele, G. (2003). Organisational Commitment: A Study of Managers in Hotels, International Journal of Contemporary Hospitality Management, 15(7), 362-369.

McFarlin, D. B., \& Sweeney, P. D. (1992). Distributive and Procedural Justice as Predictors of Satisfaction with Personal and Organizational Outcomes, Academy of Management Journal, 35(3), 626-637. 
Meyer, J. P., \& Allen, N. J. (1997). Commitment in the workplace: Theory, research, and application. (160) Sage.8-9.

Moideenkutty, U., Blau, G., Kumar, R., \& Nalakath, A. (2001). Perceived Organizational Support as A Mediator of The Relationship of Perceived Situational Factors to Affective Organizational Commitment, Applied Psychology, 50(4), 615-634.

Murat, A. K., \& Sezer, Ö. (2017). Türk Kamu Sektöründe Örgütsel Bağll1ı̆̆ın Etkileri. The Journal Of International Lingual Social And Educational Sciences, 3(2), 111-119.

O'brien, R. M. (2007). A Caution Regarding Rules of Thumb for Variance Inflation Factors, Quality \& Quantity, 41(5), 673-690.

O'Driscoll, M. P., \& Randall, D. M. (1999). Perceived Organisational Support, Satisfaction with Rewards and Employee Job Involvement and Organisational Commitment, Applied Psychology, 48(2), 197-209.

Özdevecioğlu, M. (2003). Örgütsel Vatandaşlık Davranışı ile Üniversite Öğrencilerinin Bazı Demografik Özellikleri ve Akademik Başarıları Arasındaki İlişkilerin Belirlenmesine Yönelik Bir Araştırma, Erciyes Üniversitesi İktisadi ve İdari Bilimler Fakültesi Dergisi, (20).117-135.

Özdevecioğlu, M. (2013). Algılanan Örgütsel Destek İle Örgütsel Bağlllık Arasındaki İlişkilerin Belirlenmesine Yönelik Bir Araştırma, Dokuz Eylül Üniversitesi İktisadi İdari Bilimler Fakültesi Dergisi, 18(2), 113-130.

Özdevecioğlu, M., \& Aktaş, A. G. A. (2007). Kariyer Bağlılı̆̆ı, Mesleki Bağlılık ve Örgütsel Bağlıllı̆ın Yaşam Tatmini Üzerindeki Etkisi: İ̧̧-Aile Çatışmasının Rolü, Erciyes Üniversitesi İktisadi Ve İdari Bilimler Fakültesi Dergisi, (28).1-20.

Panaccio, A., \& Vandenberghe, C. (2009). Perceived Organizational Support, Organizational Commitment and Psychological Well-Being: A Longitudinal Study, Journal of Vocational Behavior, 75(2), 224-236.

Pillai, R., Schriesheim, C. A., \& Williams, E. S. (1999). Fairness Perceptions and Trust as Mediators For Transformational and Transactional Leadership: A Two-Sample Study, Journal of Management, 25(6), 897-933.

Randall, C. S., \& Mueller, C. W. (1995). Extensions of Justice Theory: Justice Evaluations and Employees' Reactions in A Natural Setting, Social Psychology Quarterly, 58(3), 178-194.

Rhoades, L., Eisenberger, R., \& Armeli, S. (2001). Affective Commitment to The Organization: The Contribution of Perceived Organizational Support, Journal of Applied Psychology, 86, 825-836.

Robbins, Stephen P. (2003). Organizational Behavior. (Tenth Edition). New Jersey: Prentice Hall.

Roberts, J. A., Coulson, K. R., \& Chonko, L. B. (1999). Salesperson Perceptions of Equity and Justice and Their Impact on Organizational Commitment and Intent to Turnover, Journal of Marketing Theory and Practice, 7(1), 1-16.

Shore, L. M., \& Tetrick, L. E. (1991). A Construct Validity Study of the Survey of Perceived Organizational Support, Journal of Applied Psychology, 76(5), 637.

Shore, L. M., \& Wayne, S. J. (1993). Commitment and Employee Behavior: Comparison of Affective Commitment and Continuance Commitment with Perceived Organizational Support, Journal of Applied Psychology, 78(5), 774-780.

Sökmen, A., \& Şimşek, T. (2016). Örgütsel Bağlllık, Örgütle Özdeşleşme, Stres Ve İşten Ayrılma Niyeti İlişkisi: Bir Kamu Kurumunda Araştırma. Gazi Universitesi Iktisadi Ve Idari Bilimler Fakultesi Dergisi, 18(3), 606.

Tokgöz, N. (2011). Örgütsel Sinizm, Örgütsel Destek ve Örgütsel Adalet İlişkisi: Elektrik Dağıtım İşletmesi Çalışanları Örneği, Eskişehir Osmangazi Üniversitesi İktisadi ve İdari Bilimler Dergisi, 6(2).363-387. 
Tumwesigye, G. (2010). The Relationship Between Perceived Organizational Support and Turnover Intentions In A Developing Country: The Mediating Role of Organizational Commitment, African Journal of Business Management, 4(6), 942-952.

Uygur, Akyay and Kılıç, Gonca (2009). A Study into Organizational Commitment and Job Involvement: An Application Towards the Personnel İn The Central Organization for Ministry of Health in Turkey, Ozean Journal of Applied Sciences, 2 (1), 113- 125.

Wayne, S. J., Shore, L. M., \& Liden, R. C. (1997). Perceived Organizational Support and Leader-Member Exchange: A Social Exchange Perspective, Academy of Management Journal, 40(1), 82-111.

Yazıcıoğlu, İ., \& Topaloğlu, I. G. (2009). Örgütsel Adalet ve Bağlllık İlişkisi: Konaklama İşletmelerinde Bir Uygulama, İşletme Araştırmaları Dergisi, 1/1, 3-16.

Yoon, J., \& Thye, S. R. (2002). A Dual Process Model of Organizational Commitment: Job Satisfaction and Organizational Support, Work and Occupations, 29(1), 97-124.

Yozgat, U., \& Şişman, A. F. (2007). Yeniden Yapılanma Süreci ve Bunun Çalışanların İş Tatmini ve Örgüte Bağlllıkları Üzerindeki Etkisi (Bir Kamu Kurumunda Araştırma). Ulusal Yönetim ve Organizasyon Kongresi Bildiriler Kitabı, 25-27. 